\title{
EFFECT OF INTERCROPPING ON SOIL PHYSICAL AND CHEMICAL PROPERTIES IN AN OLIVE ORCHARD
}

\author{
OZTURKMEn, A. R. - RAMAZANOGLU, E. - AlmACA, A. - ÇAKMAKLI, M. \\ Department of Soil Science and Plant Nutrition, Faculty of Agriculture, Harran University, \\ Sanliurfa, Turkey \\ ${ }^{*}$ Corresponding author \\ e-mail: arozturkmen@harran.edu.tr; phone: +90-532-642-4646
}

(Received 27 Jul 2020; accepted $6^{\text {th }}$ Oct 2020)

\begin{abstract}
Conservational agricultural practices need to be implemented for improving agricultural productivity and protecting soils in a changing climate. Intercropping systems indicating multiple cropping within the same space may be used as an alternative production system which involves various plant species. This system reduces mineral $\mathrm{N}$-fertilizer use and also improves soil physical and chemical properties. Thus, this study was carried out to investigate the effects of four different intercrops (i- barley+pea, ii- barley+vetch, iii- triticale+pea, and iv- triticale+vetch) in an olive orchard on biomass yield, and some physical and chemical soil properties in a two-year field experiment in South-East Turkey. The biomass yield, soil porosity, bulk density, penetration resistance, aggregate stability, and soil organic matter content have been determined at the end of each harvest. The highest biomass yield was recorded in triticale+pea, while the lowest yield was obtained under barley+vetch treatment. A significant positive relationship was determined between aggregate stability and biomass yield, in contrast significant negative relationship was obtained between penetration resistance and biomass yield. The results of the study clearly showed that intercrops (specifically triticale+pea) can be used to produce additional biomass for animal husbandry and improve soil quality in olive tree-plantations.
\end{abstract}

Keywords: cover crop, forage crops, soil tillage, orchard, porosity, mixed cropping

\section{Introduction}

Land use change and inappropriate agricultural practices caused severe soil erosion and land degradation in semi-arid regions of Turkey (Budak et al., 2018). Approximately $85 \%$ of lands in the country are under the threat of erosion. Topographic structure and climatic conditions are natural erosion causing factors, while the lack of vegetation is a major anthropogenic factor of erosion. Therefore, establishment of vegetation on soil surface is extremely important to reduce wind and water erosion. Intercropping in orchards outside of the fruit season may contribute to alleviate the erosion, improve soil quality and meet the forage demand of livestock husbandry.

In intermediate farming with cover crops, mixing the remaining part after harvest as a green manure significantly increases soil organic matter content (Montagnini and Nair, 2004). Whyte et al. (1955) stated that intercropping of leguminous forage crops and the cereals enrich the soil organic matter. Tarman (1972) stated that the nine-year alfalfa cultivation contributed an average of 37 ton $^{-1} a^{-1}$ of organic matter to soil. Soil organic matter improves soil fertility by improving the physical and chemical properties of soils. The effect of the intercropping on soil organic matter accumulation varies depending on plant type, soil tillage and some other factors. Cultivation of forage crops with abundant above- and underground components and reduced tillage significantly increase organic matter content of soils. Cover crops in semiarid environments improve soil quality compared to frequently tilled management, by increasing organic matter content, improving the chemical and physical fertility of soils, and enhancing soil 
biological activity. Higher water extraction of cover crop plants could affect negatively the orchard growth and/or productivity; however, early cover crop removal would minimize possible yield losses. In contrast, cover crop treatments significantly increased the apricot yield compared to the control (Ramos et al., 2010).

Forage crops in intercropping have an important potential to meet roughage demand of livestock husbandry. Legumes and cereals are a source of protein and carbohydrates in animal nutrition (Ağtürk, 2010). The water infiltration of surface layer in no-tillage system is better than the that of compacted layer in the tilled lands. The plough pan constrains infiltration of water into the soil, thus water run off on the surface causes erosion. Therefore, compacted plough layer is recommended to break up every 3 to 4 years (Öztürkmen and İnce, 1998).

The porous structure of soils is lost with the tight arrangement of coarse particles due to the pressure exerted by tire or agricultural equipment and a compacted layer is formed on soil surface. Penetration resistance is closely related to pore size distribution of soils and a compacted layer contain few large pores, less total pore volume and, consequently, a greater density (Korucu et al., 2009). In general, the penetration resistance in 0-30 cm soil layer is lower than the subsurface layers $(30-60 \mathrm{~cm}$ depth). The subsurface layers contain fewer macro porous due to the pressure of upper layer soil. Penetration resistance is closely related to air and water movement in soils (Şeker, 1997). Wagner et al. (2000) indicated a positive relationship between aggregate stability, organic matter and clay content of soils. Here, researchers stated that the aggregation process is accelerated with the addition of organic matter. Soil aggregate formation is closely related to the properties of surface soils. The speed of the aggregation process in surface layer has a positive effect in minimizing the erosion threat.

Soil microorganisms decompose organic matter and turn the nutrients into plant available forms. In legume planted soils, soil mineral $\mathrm{N}$ content may increase due to the leakage form the nodules where microorganisms living symbiotically within nodules in the root systems of leguminous forage crops. Therefore, soil fertility in intercropping systems may be greater than that in monoculture cultivation (Anıl et al., 1998).

Hay yield in Turkey varies between 3 and 10 tons per hectare depending on ecological conditions. Vetch is an excellent legume forage plant that can be used as cover crop, green manure, meadow, silage or hay. Vetch has a high dry matter content and moderately resistant to cold, thus can also be sown in the winter. Polat et al. (1999) carried out a research in Ceylanpinar district of Sanliurfa province to investigate the effect of barley (Hordeum vulgare L.) + vetch (Vicia sativa L.) mixtures, grown as intercropping under rainfed conditions in Pistachio (Pistacia vera L.) orchards, on yield components. Five different forage crops sowing ratios (pure barley, $75 \%$ barley $+25 \%$ vetch, $50 \%$ barley $+50 \%$ vetch, $25 \%$ barley $+75 \%$ vetch, pure vetch) were tested in the study and the highest hay yield $\left(1020 \mathrm{~kg} \mathrm{ha}^{-1}\right)$ was obtained from $25 \%$ barley $+75 \%$ vetch mixture.

The aim of this study was to investigate the effects of different cover crop treatments tested as intercropping in an olive orchard on some soil quality parameters and biomass yield. Soil organic matter, total nitrogen, electrical conductivity, basal soil respiration, structural stability index, aggregate stability, saturated hydraulic conductivity, bulk density, permanent wilting point, field capacity and available water content of soil samples were determined as soil quality indicators. 


\section{Materials and Methods}

The study site is located in the Harran Plain, Şanliurfa, Turkey $\left(37^{\circ} 9.7^{\prime} \mathrm{N}\right.$ Lat, $38^{\circ}$ 58.7 E Long). The field site has a semi-arid climate with a mean annual temperature, precipitation, and evaporation of $17.2{ }^{\circ} \mathrm{C}, 365.2 \mathrm{~mm}$, and $1848 \mathrm{~mm}$, respectively (from 2000 to 2015). Elevation of the study area ranges from 358 to $530 \mathrm{~m}$. This two-year study was carried out in an olive orchard consisted of 12 plots, where 15-16 year old olive trees planted at $6 \times 6 \mathrm{~m}$ distances in the Kisas village, representing the Harran Plain of Şanliurfa, Turkey (Fig. 1). The field was tilled with a small garden plow and leveled with a cultivator. A hand-held scythe was used for moving the weeds.

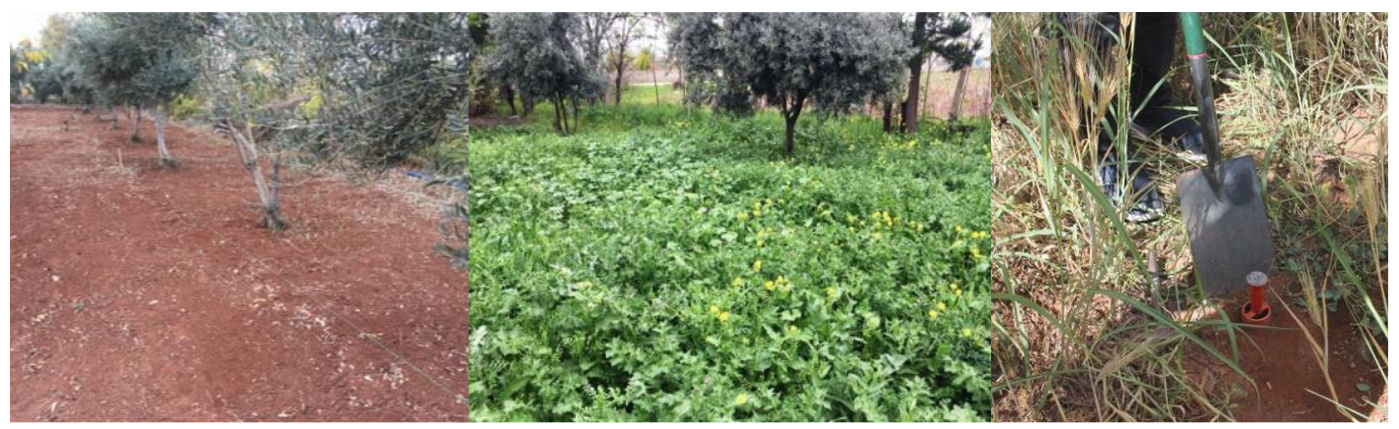

Figure 1. Experimental site and soil sampling

Disturbed and undisturbed soil samples were collected from 0-20 $\mathrm{cm}$ depth prior to soil tillage, and soil properties of the olive orchard were given in Table 1.

Table 1. Soil properties of experimental field prior to tillage

\begin{tabular}{c|c}
\hline Soil Properties & Depth $\mathbf{0}-\mathbf{2 0} \mathbf{~ c m})$ \\
\hline Moisture content $(\%)$ & 13.21 \\
Bulk density $\left(\mathrm{g} \mathrm{cm}^{-3}\right)$ & 1.31 \\
Porosity $(\%)$ & 50.45 \\
Penetration resistance (MPa) & 0.90 \\
$\mathrm{pH}$ & 7.98 \\
Lime (\%) & 21.25 \\
Electrical conductivity (dS m$\left.{ }^{-1}\right)$ & 0.275 \\
Organic matter $(\%)$ & 1.14 \\
\hline
\end{tabular}

Four different mixtures, which were widely used in the region were tested as forage crop mixtures.

1. Mixture: Common vetch + barley $(10 \mathrm{~kg}$ common vetch $+5 \mathrm{~kg}$ barley)

2. Mixture: Common vetch + Triticale $(10 \mathrm{~kg}$ common vetch $+5 \mathrm{~kg}$ Triticale)

3. Mixture: Forage pea + Barley (10 kg Forage pea $+5 \mathrm{~kg}$ Barley)

4. Mixture: Forage pea +Triticale (10 kg Forage pea $+5 \mathrm{~kg}$ Triticale)

Forage crops were planted in early November 2017 and 2018 and harvested in the first week of May. Soil samples were collected following the harvest of each year at the same time and biomass yield was also calculated for each year. The common vetch, 
barley, triticale and forage pea mixtures, which are widely preferred in the region, were used in experiment. The experiment was laid out in randomized blocks with 3 blocks and $4 \times 6 \mathrm{~m}$ plots between the olive trees. Fertilizers usually is not applied for winter forage crops (Carr et al., 2004), therefore we did not use any nitrogen and phosphorus fertilizers in this study. Seeds were sown manually following two tillage operation with a cultivator in November. The seeds were not planted at a distance of $1 \mathrm{~m}$ to the olive trees. The plants were harvested manually at the beginning of May, when 1/3 of the plants were flowering, dried in the field and removed.

\section{Soil Sampling and Preparation to Laboratory Analysis}

Three soil samples representing the experimental field were taken prior to the planting. After the harvest in each year, soil samples were collected from 0-30 cm depth of each plot (12 plots). Soil samples were air dried under room temperature, rocks and roots were removed, grinded by a wood roller and sieved through $2 \mathrm{~mm}$ sieve for laboratory analysis.

\section{Soil Analysis}

Soil reaction $(\mathrm{pH})$ (Richards, 1954), calcium carbonate content (\%) (Allison and Moodie, 1965), electrical conductivity (EC, dS $\mathrm{m}^{-1}$ ) (Jackson, 1962), organic matter content (\%) (Kacar, 2009), bulk density (Blake and Hartge, 1986), water content at field capacity, permanent wilting point and available water content (Klute, 1986), aggregate stability (Kemper and Rosenau, 1986) of soil samples were determined. Penetration resistance was measured using a penetrometer (Say and Işık, 1996). Plant available phosphorus content was determined in spectrophotometer (Olsen et al., 1954). Extractable magnesium, potassium and calcium contents (Warncke and Brown, 2011), and DTPA extractable zinc, iron, manganese and cupper contents (Lindsay and Norvell, 1978) were determined in an atomic absorption spectrophotometer (Olsen et al., 1954).

\section{Statistical Analysis}

The effects of cover crop treatments on biomass yield and some of physical and chemical properties of soils were evaluated using a one-way analysis of variance (ANOVA). Post-Hoc LSD test was carried out where ANOVA indicated a statistically significant differences. All statistical analyses were carried out using SPSS 21 (SPSS Inc., Chicago, IL, USA) statistical software.

\section{Result}

\section{Biomass Yield}

Mean biomass yield in intercropping treatments during 2018 and 2019 seasons were presented in Fig. 2. The biomass yield of respective treatments varied between 1940 to $2610 \mathrm{~kg}$ fresh dry matter ha- ${ }^{-1}$. The highest biomass yield in both years was obtained in triticale + pea treatment. The forage pea mixtures in the intercropping caused a higher yield compared to the common vetch mixtures. The lowest yield in both years was recorded in barley + vetch treatments. Biomass yield in 2019 was slightly higher than that in 2018 , however, relative differences among treatments were similar. 


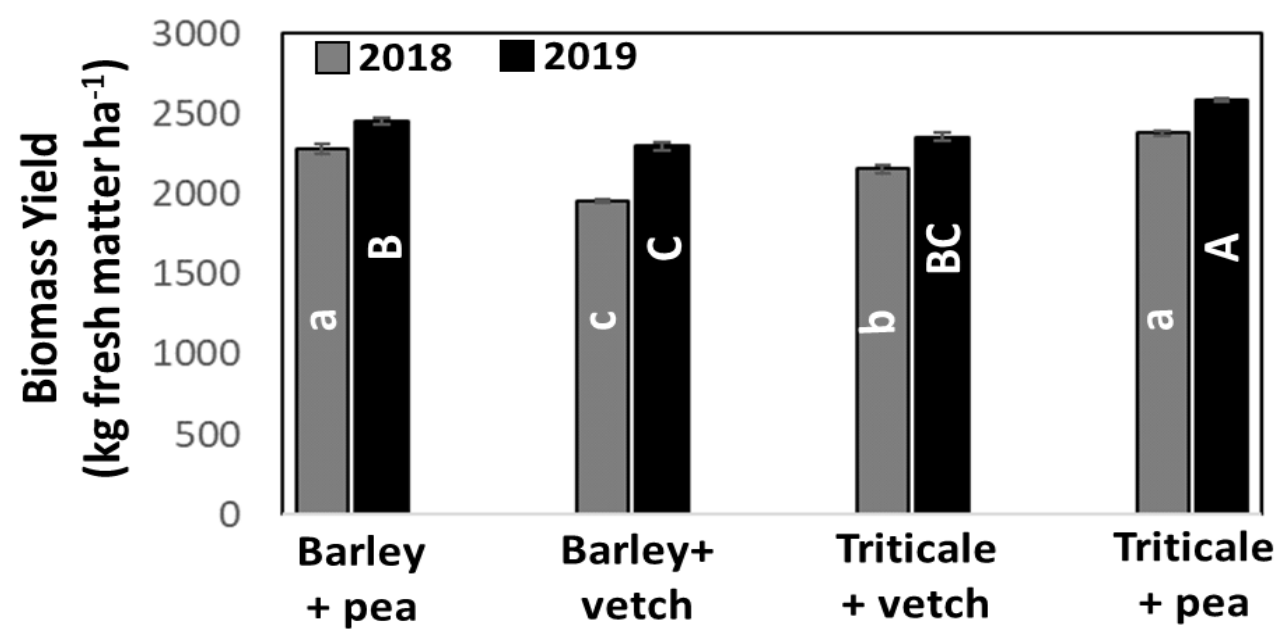

Figure 2. Biomass yield of various intercrop treatments in 2018 and 2019. Data presented as the mean value of 4 replicates $(n=3)$. Error bars represent the standard error of 3 replicates. Small or capital letters represent the statistical differences among treatments within each year

\section{Aggregate Stability}

Aggregate stability measured at the end of each season was presented in Table 2. There was a clear differences among treatments in both years with similar trends. The aggregate stability was higher in pea mixed intercropping as compared to the vetch mixture. The highest aggregate stability was measured barley+pea treatment, while the lowest was measured in triticale+vetch treatment. The statistical analysis showed no differences in aggregate stability between the years. The aggregate stability of the respective treatments followed the trend, barley+pea $>$ triticale+pea $>$ barley+vetch $>$ triticale+vetch.

Table 2. Effect of cover crops on some soil physical and chemical properties determined in 2018 and 2019 growing seasons

\begin{tabular}{|c|c|c|c|c|c|c|c|c|c|}
\hline \multirow[t]{2}{*}{ Year } & \multirow{2}{*}{$\begin{array}{l}\text { Crop } \\
\text { type }\end{array}$} & $\begin{array}{l}\text { gregate } \\
\text { tability }\end{array}$ & Porosity & $\begin{array}{c}\text { Bulk } \\
\text { Density }\end{array}$ & $\begin{array}{c}\text { Field } \\
\text { Capacity }\end{array}$ & $\begin{array}{c}\text { Wilting } \\
\text { Point }\end{array}$ & $\begin{array}{c}\text { Available } \\
\text { Water }\end{array}$ & $\begin{array}{c}\text { Penetration } \\
\text { Resistance }\end{array}$ & $\begin{array}{l}\text { Organic } \\
\text { Matter }\end{array}$ \\
\hline & & $\%$ & & & $(\%)$ & $(\%)$ & $(\%)$ & Mpa & $(\%)$ \\
\hline 018 & & $.7 \pm 0.01 \mathrm{a}$ & & $4 \pm 0.02 *$ & $37.09 \pm 0.88^{*}$ & $27.16 \pm 0.35 *$ & $9.93 \pm 0.56 \mathrm{~b}$ & $0.82 \pm 0.02 *$ & $1.25 \pm 0.01 *$ \\
\hline 018 & $\begin{array}{l}\text { Barley } \\
\text { +vetch }\end{array}$ & & $.59 \pm 0.02 \mathrm{ab}$ & $1.18 \pm .0 .01$ & $37.69 \pm 0.41$ & $24.46 \pm 0.36$ & $13.23 \pm 0.18 \mathrm{a}$ & $0.87 \pm 0.02$ & $1.21 \pm 0.01$ \\
\hline 018 & $\begin{array}{c}\text { Triticale } \\
\text { +vetch }\end{array}$ & $13.85 \pm 0.15 \mathrm{~d}$ & $0.58 \pm 0.01 \mathrm{ab}$ & $1.19 \pm 0.01$ & $37.22 \pm 0.18$ & $28.18 \pm 0.22$ & $9.04 \pm 0.28 \mathrm{~b}$ & $0.85 \pm 0.03$ & $1.29 \pm 0.01$ \\
\hline 2018 & $\begin{array}{c}\text { Triticale } \\
+ \text { pea }\end{array}$ & $23.23 \pm 0.36 \mathrm{~b}$ & $057 \pm 0.02 \mathrm{a}$ & $1.20 \pm 0.04$ & $36.52 \pm 1.02$ & $27.21 \pm .0 .63$ & $9.32 \pm 0.71 \mathrm{~b}$ & $0.85 \pm 0.03$ & $1.21 \pm 0.01$ \\
\hline 2019 & $\begin{array}{c}\text { Barley } \\
\text { +pea }\end{array}$ & $26.66 \pm 0.37 \mathrm{a}$ & $0.64 \pm 0.01 *$ & $1.18 \pm 0.01 *$ & $37.30 \pm 0.23 *$ & $27.33 \pm 0.51 *$ & $9.98 \pm 0.41 b$ & $0.72 \pm 0.02 *$ & $1.55 \pm 0.05 *$ \\
\hline 2019 & $\begin{array}{l}\text { Barley } \\
\text { +vetch }\end{array}$ & $21.24 \pm 0.50 \mathrm{c}$ & $0.61 \pm 0.02$ & $1.21 \pm 0.01$ & $37.70 \pm 0.14$ & $25.88 \pm 0.28$ & $11.82 \pm 0.42 \mathrm{a}$ & $0.77 \pm 0.02$ & $1.54 \pm 0.01$ \\
\hline 2019 & $\begin{array}{c}\text { Triticale } \\
\text { +vetch }\end{array}$ & $15.82 \pm 0.23 \mathrm{~d}$ & $0.72 \pm 0.11$ & $1.21 \pm 0.01$ & $37.19 \pm 0.29$ & $27.68 \pm 0.45$ & $9.50 \pm 0.42 b$ & $0.75 \pm 0.03$ & $1.66 \pm .001$ \\
\hline 2019 & $\begin{array}{c}\text { Triticale } \\
+ \text { pea }\end{array}$ & $24.35 \pm 0.40 \mathrm{~b}$ & $0.65 \pm 0.09$ & $1.21 \pm 0.01$ & $37.42 \pm 0.44$ & $27.73 \pm .0 .42$ & $9.70 \pm 0.18 \mathrm{~b}$ & $0.77 \pm 0.02$ & $1.54 \pm 0.01$ \\
\hline
\end{tabular}

Data presented as the mean value of 4 replicates $(n=3) . *$ indicates no significant differences 


\section{Porosity}

The effect of various intercropping treatments on porosity measured at the end of each growing season was presented in Table 2 . Soil porosity varied significantly among the treatments in both years with similar trends. Similar to the aggregate stability, porosity in 2018 was higher in pea mixed barley treatment as compared to the others. The porosity of barley included treatments was generally higher in 2018 , however no differences was found in 2019. The porosity in 2019 was slightly higher in all treatments as compared to that in 2018 .

\section{Available Water}

Plant available water content measured in various cover crop treatments was given in Table 2. Plant available water content measured in barley+pea mixture was significantly higher as compared to the other treatments in both years. The available water content in all other treatments remained similar without any significant differences. The highest mean available water content $(13.2 \pm 0.18 \%)$ in 2018 was recorded in barley+pea treatment, which was ranged from 9.0 to $9.9 \%$ in other treatments. The mean available water content in 2019 was obtained in barley+pea treatment $(11.8 \pm 0.18 \%)$ and varied between 9.5 to 10.0 in other treatments.

\section{Other Soil Parameters}

Bulk density, field capacity and wilting point water contents, penetration resistance and organic matter content of soil samples were presented in Table 2. The values of these parameters were slightly different among the treatments, however the differences were not statistically significant among the treatments. Soil organic matter content in 2019 was slightly higher as compared to that in 2018. The difference in soil organic matter content between the years can be attributed the biomass incorporation of cover crop treatments. The above ground biomass were not removed from the field, in contrast incorporated to the soil, which likely caused such temporary increase in organic matter content.

\section{Discussion}

Most cropping systems in the world are dominated by a low number of crop species and genotypes. For example, $60 \%$ of arable land is devoted to a set of three cash crops (maize, winter wheat and oilseed rape). In addition, the grasslands are under high pressure of livestock grazing and the number of relevant species are decreasing by time. Many forests and other woody stands such as short rotation forests are still managed as monocultures, although during the last three decades many mature pure stands have been converted to mixed stands. In our approach we suggest, based on proven expertise, that mixed or multi species stands could be considered as an element to facilitate both agrobiodiversity and productivity. Diverse crop stands is expected to improve resilience and increase overall yield compared to the corresponding monoculture. Unfortunately, general valid explanation and verification across land-use systems have not been provided yet; thus the biodiversity and productivity relationship has not been explained clearly. Moreover, in those cases where mixed cropping systems were established, breeding and especially official testing have been intended to improve the performances in pure stand (single crop stands, mono culture). 
Intercropping is a rather prominent farming system in conservational agriculture, due to the significant advantages in yield and its beneficiary effects on soil properties. The main advantages of the intercropping system are the increase in yield potential without additional input (such as mineral fertilizer) and the increase in buffering against stress and other negative circumstances. Intercropping receives growing interest in temperate climate zones (Lauk and Lauk, 2008). The review on intercropping revealed that the mixtures had a favorable mixing effect in $60 \%$ of 344 cases (Li et al., 2006). Intercrop components do not compete with the identical ecological niches. Two important mechanisms were reported between legume and non-legume intercrops. The first mechanism is the rhizo-deposition of nitrogen in legumes and subsequent nitrogen transfer can promote yield of the non-legume crops. Similar transfer mechanism have been reported for phosphorous ( $\mathrm{Li}$ et al., 2006). Hauggaard-Nielsen et al. (2001) observed faster and deeper growing barley roots in intercrop stands with pea compared to single barley cultivation. Thus, a greater soil volume was available for the mixed intercrop compared to the single crops. Similarly, soil porosity and other soil physical parameters were positively affected by the mixed crop stands. The barley + cereal mixture caused a significant increase in porosity and aggregate stability which likely increased the available soil water content. In addition, positive relationship was obtained between biomass yield of mixed stands and aggregate stability (Fig. 3A). Penetration resistance is an important indicator of root growth and storage of soil water. Significant correlation was recorded between yield and penetration resistance of soil.
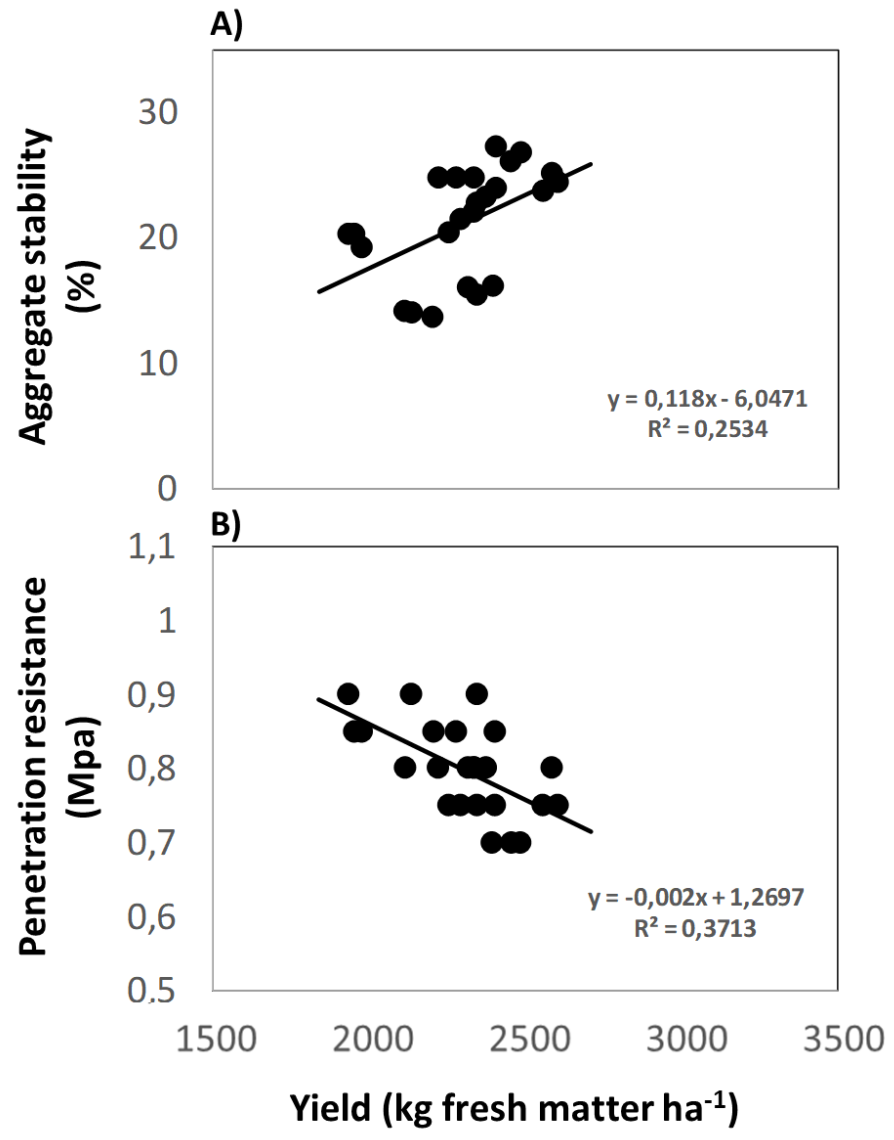

Figure 3. Relationship between aggregate stability $(A)$, penetration resistance $(B)$ and biomass yield of various intercrops (data pooled for 2018 and 2019) 
Microorganisms in soils use organic matter as food and excess nutrients are released while decomposition of organic matter by microorganisms. Fixation of atmospheric nitrogen by microorganisms, especially through symbiosis with legume forage crops, enhances the nitrogen content of soils. Healthy growth of forage crops increases phosphorus and potassium uptake of roots and improves the availability of nutrients in soils (Barber, 1989). Therefore, intercropping is more productive than monoculture (Anil et al., 1998). Forage crops produced in intercropping have an important potential in meeting the forage demand of livestock husbandry. Legume and cereals are important sources of protein and carbohydrates in animal nutrition (Ağtürk, 2010). In this study, approximately 2-3 tons per hectare forage obtained from legume + cereal mixture grown between olive trees shows that intercropping may be a good opportunity to develop animal husbandry in the region. In addition, high nitrogen content (due to the legume mixture) of forage increases the feed quality in animal nutrition. Hay yield in Turkey varies between 3 to 10 tons per hectare depending on the ecological characteristics of the region (Hatipoglu et al., 2009). Vetch is an excellent legume forage plant that can be used as cover crop, green manure, meadow, silage and hay. The vetch, which has a high dry matter content, fixes nitrogen similar to the other legumes, is grown in the winter, and is moderately resistant to cold. The vetch can be grown by mixing with other forage crops or can be grown alone in the field, or the vetch can be cultivated by mixing or alone as intercropping in vineyards and orchards. Polat et al. (1999) carried out a research in Ceylanpınar district of Sanliurfa province to investigate the effect of barley (Hordeum vulgare L.) + vetch (Vicia sativa L.) mixtures, grown as intercropping under rainfed conditions in Pistachio (Pistacia vera L.) orchards, on yield components. Five different forage crops sowing ratios (pure barley, $75 \%$ barley $+25 \%$ vetch, $50 \%$ barley $+50 \%$ vetch, $25 \%$ barley $+75 \%$ vetch, pure vetch) were tested in the study and the highest hay yield $\left(1020 \mathrm{~kg} \mathrm{ha}^{-1}\right)$ was obtained from $25 \%$ barley $+75 \%$ vetch mixture. The highest yield in this study was obtained in triticale + pea mixture.

Southeastern Anatolia Region of Turkey has 6 million ha land planted by pistachio, olive, peach, apple and apricot. The results of this study indicated that the orchard fields can be used to grow forage crops as intercropping. The lack of vegetative cover on soil surface causes severe soil erosion and land degradation; and prevents the production of forage crops, which is one of the most important inputs of livestock husbandry. Soil water content ranged from 7.1 to $34.5 \%$ during the intercropping growth season. The porosity of soils was between 48 and $57 \%$ which indicates that the water saturation of soils is at most between 61 and $72 \%$. The results reveals that especially the sub-surface layers are mostly not saturated. Soil water content of surface soils in barley treatments varied between 11.3 and $19.4 \%$, and the lowest soil water content was recorded in single barley treatment, followed by vetch and mixture of vetch + barley. The results of the first year revealed no serious competition for water use between the forage crops and olive trees until the end of the growth season. However, reliable evaluation for perennial plants can be made only by taking the results of long-term studies into account. The results of current study indicate that cultivation of barley + pea or triticale + vetch mixture as intercropping can contribute to agricultural production, soil quality and sustainable agriculture in the semi-arid regions. 


\section{Conclusion}

Overall, the present study clearly demonstrates that the cultivation of barley + pea or triticale + vetch mixture as intercropping may significantly improve soil quality in the semi-arid regions. Cereal-legume mixed-intercropping caused a significant change in porosity and aggregate stability which likely affect the available soil water content. A significant positive relationship was determined between aggregate stability and biomass yield, in contrast significant negative relationship was obtained between penetration resistance and biomass yield. The results of the study clearly showed that intercrops (specifically triticale+pea) can be used to produce additional biomass for animal husbandry and improve soil quality in olive tree planted lands plantations. Further research is needed to understand the mechanisms on how soil rhizosphere processes controls soil chemical and physical parameters in mixed cropping systems.

Acknowledgement. Authors would like to thank Assoc. Prof. Dr. Mehmet ŞENBAYRAM in Harran University for his help during the organization of the field studies and editing the manuscript. This study was funded by Harran University Scientific Research Coordination Unit (HÜBAK) (Project No: 17091).

\section{REFERENCES}

[1] Ağtürk, R. (2010): Effects of Forage Plants Grown as Intercropping in Pistachio Orchards on Soil Water Content. - Kahramanmaraş Sütçü İmam University, Institute of Science, Department of Soil Science, M.Sc. Thesis, Kahramanmaraş.

[2] Allison, L. E., Moodie, C. D. (1965): Carbonate. - In: Black, C. A. (ed.) Methods Of Soil Analysis. Part 2, Agronomy No. 9, Asa, SSSA, WI, USA, pp. 1379-1400.

[3] Anıl, L., Park, J., Phipps, R. H., Miller, F. A. (1998): Temperate Intercropping Of Cereal Forage: A Review Of The Potential For Growth And Utilization With Particular Reference To The UK. - Grass And Forage Science 53: 301-317.

[4] Barber, S. A. (1989): Soil Nutrient Availability: A Mechanistic Approach. - John Wiley And Sons, New York.

[5] Blake, G. R., Ve Hardge, K. H. (1986): Bulk Density. - In: Methods Of Soil Analysis, Part 1, $2^{\text {nd }}$ ed., Agronomy 9, ASA and SSSA, Madison, WI, pp. 363-375.

[6] Budak, M., Günal, H., Çelik, İ., Yıldız, H., Acir, N., Acar, M. (2018): Environmental sensitivity to desertification in northern Mesopotamia; application of modified MEDALUS by using analytical hierarchy process. - Arabian Journal of Geosciences 11(17): 481.

[7] Carr, P. M., Horsley, R. D., Polve, W. W. (2004): Barley, Oat, And Cereal-Pea Mixtures As Dry Forages İn The Northern Great Plains. - Agronomy J. 96: 677-684.

[8] Danielson, R. E., Sutherland, P. L. (1986): Porosity. - In: Klute, A. (ed.) Methods Of Soil Analysis. Part 1: Physical And Mineralogical Methods, $2^{\text {nd }}$ ed., Agronomy 9, ASA and SSSA, Madison, WI, pp. 443-461.

[9] Demir, Z., Tursun, N., Işık, D. (2019): Effects Of Different Cover Crops On Soil Quality Parameters And Yield İn An Apricot Orchard. - Intl. J. Agric. Biol. 21: 399-408.

[10] Hatipoğlu, R., Avcioğlu, R., Karadağ, Y. (2009): The Place of Forage Crops in Sustainable Agriculture. - In: Avcıŏglu, R., Hatipoğlu, R., Montenegro, Y. (eds.) Forage Crops. Volume I. General Section, General Directorate of Agricultural Production and Development, Turkey, Emre Publishing House, İzmir.

[11] Hauggaard-Nielsen, H., Jensen, E. (2001): Evaluating pea and barley cultivars for complementarity in intercropping at different levels of soil $\mathrm{N}$ availability. - Field Crops Research 72: 185e196.

[12] Jackson, M. L. (1962): Soil Chemical Analysis. - Constable and Co. Ltd., London. 
[13] Kacar, B. (1994): Chemical Analysis of Plants and Soils: Soil Analysis. - Ankara Univ. Agricultural Faculty, Education Research and Development Foundation Publications No.3.

[14] Kacar, B. (2009): Soil Analysis. - Nobel Publishing Distribution (Extended 2 ${ }^{\text {nd }}$ Edition) No: 1387. 93p. Ankara.

[15] Kemper, W. D., Rosenau, R. C. (1986): Aggregate Stability And Size Distribution. - In: Klute, A. (ed.) Methods Of Soil Analysis. Part 1: Physical And Mineralogical Methods, $2^{\text {nd }}$ ed., Agronomy 9, ASA and SSSA, Madison, WI, pp. 425-442.

[16] Klute, A. (1986): Water Retention: Laboratory Methods. - In: Klute, A. (ed.) Methods Of Soil Analysis. Part 1, $2^{\text {nd }}$ ed., Agronomy 9, Am. Soc. Agron., Madison, WI, pp. 635-660.

[17] Korucu, T., Arslan, S., Günal, H., Şahin, M. (2009): Spatial and temporal variation of soil moisture content and penetration resistance as affected by post-harvest period and stubble burning of wheat. - Fresenius Environmental Bulletin 18(9A): 1736-1747.

[18] Lauk, C., Krausmann, F., Erb, K.-H., Gingrich, S., Haberl, H. (2008): Global patterns of socioeconomic biomass flows in the year 2000: A comprehensive assessment of supply, consumption and constraints. - Ecological Economics 65(3): 471-487. doi:10.1016/j.ecolecon.2007.07.012.

[19] Li, C., Farahbakhshazad, N., Jaynes, D. B., Dinnes, D. L., Salas, W., McLaughlin, D. (2006): Modeling nitrate leaching with a biogeochemical model modified based on observations in a row-crop field in Iowa. - Ecological Modelling 196(1-2): 116-130. doi:10.1016/j.ecolmodel.2006.02.007.

[20] Lindsay, W. L., Norvell, W. A. (1978): Development of a DTPA Soil Test For Zinc, Iron, Manganese, And Copper. - Soil Science Society of America Journal 42: 421-428.

[21] Lithourgidis, A. S., Dhima, K. V., Vasilakoglou, I. B., Dordas, C. A., Yiakoulaki, M. D. (2007): Sustainable Production Of Barley And Wheat By İntercropping Common Vetch. - Agron Sustain Dev 27: 95-99.

[22] Martinez-Casasnovas, J. A., Ramos, M. C. (2006): The Cost Of Soil Erosion İn Vineyard Fields İn The Penedes-Anoia Region (Ne Spain). - Catena 68: 194-199.

[23] Montagnını, F., Nair, P. K. R. (2004): Carbon Sequestration: An Underexploited Environmental Benefit Of Agroforestry Systems. - Agroforestry Systems 61: 281-295.

[24] Olsen, S. R., Cole, C. V., Watanabe, F. S., Dean, L. A. (1954): Estimation Of Available Phosphorus İn Soils By Extraction With Sodium Bicarbonate. - U.S. Dept. Agric. Cric. 939.

[25] Öztürkmen, A. R., İnce, F. (1998): The Effect of Hard Layer Breaking on Cotton Yield in Harran Plain. - M. Şefik Yeşilsoy International Symposium On Arid Region Soils, 21-24 September 1998, pp. 512-518. Menemen / İzmir.

[26] Polat, T., Acar, İ., Baysal, İ., Ş1lbır, Y., Ak, B. E. (1999): Investigations on the Effect of Vetch (Vicia Sativa L.) + Barley (Hordeum Vulgares L.) Mixture Ratios that Can Be Grown as Sub Plants in Ceylanpınar rainfed Conditions on Pistachio (Pistacio Vera L.) Plantations. - Proceedings of GAP I. Agricultural Congress, Şanlıurfa, pp. 821-828.

[27] Ramos, M. E., Benítez, E., García, P. A., Robles, A. B. (2010): Cover Crops Under Different Managements Vs. Frequent Tillage İn Almond Orchards İn Semiarid Conditions: Effects On Soil Quality. - Applied Soil Ecology 44(1): 6-14.

[28] Richards, L. A. (1954): Diagnosis And Improvement Saline And Alkaline Soils. - U.S. Dep. Agr. Handbook 60.

[29] Say, S. M., Işık, A. (1996): A Research on Determination of Penetration Resistance with Soil Conditions. $-6^{\text {th }}$ International Agricultural Mechanization and Energy Congress, Ankara.

[30] Stocking, M. A. (1994): Assessing Vegetation Cover And Management Effects. - In: Lal, R. (ed.) Soil Erosion Research Methods. $2^{\text {nd }}$ ed. Soil And Water Conservation Society, St. Luicie Press, Ankeny, pp. 208-232.

[31] Şeker, C. (1997): Relationships Between Penetration Resistance and Some Soil Properties. - Turkish. J. of Agriculture and Forestry 23(Supplement 3): 583-588. 
[32] Tarman, Ö. (1972): Forage Crops, Meadow And Pasture Culture. - Volume 1, General Principles. Ankara Univ. Faculty of Agriculture Publications (464.157), Ankara.

[33] Unger, P. W., Vigil, M. F. (1998): Cover Crop Effect On Soil Water Relationships. Journal Soil And Water Conservation 53(3): 200-207.

[34] Wagner, S., Cattle, S. R., Scholten, T., Felixhenningsen, P. (2000): Observing The Evolution Of Soil Aggregates From Mixtures Of Sand, Clay And Organic Matter. - New Zealand Society Of Soil Science 3: 217-218.

[35] Warncke, D., Ve Brown, J. R. (2011): Potassium And Other Basic Cations. - In: Recommended Chemical Soil Test Procedures For The North Central Region. North Central Regional Publication No. 221 (Revised), USA, pp. 31-35.

[36] Whyte, R. O., Fissner, G. N., Trumble, H. C. (1955): Les Legumineuses En Agriculture. - Etudes Agricoles De La Fao, No: 21, Rome, Italia, p. 45. 